\title{
Cranberry is not effective for the prevention or treatment of urinary tract infections in individuals with spinal cord injury
}

\author{
EA Opperman \\ Department of Family Relations and Applied Human Nutrition, University of Guelph, Guelph, Ontario, Canada
}

\begin{abstract}
Study design: Literature review.
Objectives: Urinary tract infections (UTIs) are the most common medical complication experienced by individuals with spinal cord injury $(\mathrm{SCl})$. Recent research presents conflicting evidence regarding use of cranberry in reducing growth and colonization of uroepithelial cells by uropathogenic bacteria. The objective was to determine whether the literature supports the use of cranberry in preventing or treating UTIs in the $\mathrm{SCl}$ population.

Methods: MEDLINE was searched for intervention studies, which investigated the use of cranberry in the prevention or treatment of UTIs in the SCI population. If the studies met the inclusion criteria, full articles were located and reviewed.

Results: Five studies (four randomized clinical control - three trials using cranberry tablets vs placebos and one using cranberry juice - and one pilot study using cranberry juice) were identified which evaluated the effectiveness of cranberry products for the prevention or treatment of UTIs in the SCI population. Three studies reported no statistically significant effect of cranberry tablets in urinary $\mathrm{pH}$, urinary bacterial count, urinary white blood cell (WBC) count, urinary bacterial, and WBC counts in combination or episodes of symptomatic UTIs. A fourth study showed that cranberry juice intake significantly reduced biofilm load compared with baseline. A final study reported fewer UTIs during the period with cranberry extract tablets vs placebo.

Conclusions: Limited evidence from clinical trials that vary in design suggests that cranberry, in juice or supplement form, does not seem to be effective in preventing or treating UTIs in the SCI population. More rigorous clinical research is needed to confirm this.
\end{abstract}

Spinal Cord (2010) 48, 451-456; doi:10.1038/sc.2009.159; published online 24 November 2009

Keywords: cranberry; urinary tract infection; spinal cord injury; alternative medicine; neurogenic bladder

\section{Introduction}

The incidence of spinal cord injury (SCI) varies widely from country to country; however, worldwide, it is $\sim 40$ per million people. ${ }^{1}$ Individuals with SCI face many years of survival with severe disability, as the majority of injuries are sustained under the age of 34 years. $^{2}$ Although life expectancy has improved in the SCI population, individuals are susceptible to numerous diseases and secondary impairments as a result of their injuries increasing the risk of premature death. ${ }^{3,4}$

Urinary tract infections (UTIs) are the most common medical complication experienced by individuals living with SCI. ${ }^{5-10}$ UTIs are a problem during initial hospitalization,

Correspondence: EA Opperman, Department of Family Relations and Applied Nutrition, University of Guelph, Macdonald Stewart Hall, Room 329, 50 Stone Road East, Guelph, Ontario, Canada N1G 2W1.

E-mail: eopperma@uoguelph.ca

Received 3 September 2009; revised 13 October 2009; accepted 13 October 2009; published online 24 November 2009 after discharge $e^{5,11}$ and are a main cause of rehospitalization in this population. ${ }^{12}$ Individuals will suffer from a symptomatic UTI at some point after disability ${ }^{13}$ and will experience between 1.82 and 2.6 symptomatic UTIs per year. ${ }^{14-16}$ Consequently, UTIs intensify the experience of disability, threaten survival, negatively impact long-term health, dignity, mobility, independence, and quality of life. ${ }^{4,14,15}$ The high prevalence of UTIs is also costly to the health care system. ${ }^{4,12}$

Several factors are responsible for the high prevalence of UTIs including invasive procedures without antibiotic prophylaxis, cervical injury, neurogenic bladder, stagnant residual urine, incomplete voiding, catheter use, and elevated intravesical pressure. ${ }^{14,15,17}$ These factors commonly cause chronic or recurrent bacteriuria, which may remain asymptomatic or progress to symptomatic UTI. ${ }^{5}$ Treating UTIs can be complicated because of polymicrobial bacteria, multi-drug-resistant bacteria, side effects of the 
drugs themselves, and recolonization of the bladder once treatment is discontinued. ${ }^{5,17-19}$ Multi-drug-resistant bacteria can result in life-threatening complications. ${ }^{1}$ As a result, asymptomatic bacteriuria is frequently left untreated until it becomes symptomatic as asymptomatic bacteriuria is not associated with adverse urological outcomes in the SCI population. ${ }^{19,20}$

Concerns regarding the overuse of antibiotics in individuals with SCI has prompted consideration for consumer-directed alternatives to improve urinary tract health. ${ }^{5,18,19}$ Dietary supplement use is high in the SCI population, and preventing UTIs is the primary reason for taking cranberry. ${ }^{21}$ Cranberry is thought to improve urinary tract health by inhibiting the adhesion of uropathogenic bacteria to the uroepithelial cells by interfering with specific receptor-ligand modes of microbial adhesion. 5,18,22-26 Cranberries contain proanthocyanidins and fructose, which specifically inhibit hemagglutination of Escherichia coli by the expression of types 1 and $\mathrm{P}$ adhesion. ${ }^{27-30}$ Cranberry juice is more effective at preventing bacterial adherence than displacing bacteria already attached to the epithelial cells. ${ }^{31}$ In the able-bodied population, there is some evidence to recommend cranberry to prevent symptomatic UTIs in women with recurrent UTIs; however, the evidence is inconclusive as to whether it is effective in older adults. $^{32}$

Whether cranberry may be useful in preventing or treating UTIs in people with SCI may be a valuable information for clinicians and researchers because $>40 \%$ of people with physical disabilities use alternative medicine to treat medical conditions and cranberry is a frequently consumed supplement. ${ }^{10,21}$ Clinicians need to be aware of why individuals with SCI consume cranberry and whether cranberry will improve their condition. Furthermore, they need to be aware of the literature available to make educated decisions regarding the appropriate means of consumption and dosage to present to their clients. The objective of this review was to determine whether the literature supports the use of cranberry in preventing and/or treating UTIs in the SCI population.

\section{Materials and methods}

Intervention studies, which investigated the use of cranberry - either in supplement or juice form - to aid in the prevention or treatment of UTIs specifically in the SCI population were eligible for this review. Only studies with human subjects and participants with SCI (paraplegia or tetraplegia) were included. Articles eligible for this review were searched through MEDLINE. Combinations of the following search terms were used: cranberry, UTI, SCI, treatment, prevention, urinary stasis, neurogenic bladder, bacteriuria, and pyuria. All identified papers were initially read by title and abstract. If the studies met the inclusion criteria, full articles were located and reviewed. In addition, reference lists of suitable publications were searched manually for additional articles.

\section{Results}

Numerous articles were identified which evaluated the effectiveness of cranberry in preventing or treating UTIs in the healthy ambulatory population. These were not included. Five studies were identified which evaluated the effectiveness of cranberry products for the prevention or treatment of UTIs in the SCI population. ${ }^{5,6,11,18,19}$ All participants in the studies were individuals with SCI (paraplegia or tetraplegia) and neurogenic bladder. Additional criteria for Hess et al. included participants with ASIA A, B, or C classification and excluded participants with SCI <1-year duration, a glomerular filtration rate of $<30 \mathrm{ml} \mathrm{min}^{-1}$, immunosuppressive medications, or current malignancy. ${ }^{11}$ Reid et al. included participants over 18 years of age, with earlier history of UTI, were not pregnant, were not receiving prednisone or immunosuppressive drugs, had no history of autonomic dysreflexia as a result of UTI in the past 12 months, no known urinary abnormality and did not have symptomatic UTI at the time of the study. ${ }^{18}$ Lee et al.'s additional criteria included participants with stable bladder management with indwelling urethral or suprapubic catheter, intermittent catheterization or reflex voiding, absence of complex urological or serious renal or hepatic pathology, not being prescribed antibiotics, and absence of symptoms of UTI at time of enrolment. ${ }^{19}$ Waites et al. required participants to be at least 1-year post-SCI, >16 years of age, use intermittent catheterization or external collection device, no systemic antimicrobials or urinary acidifying agents taken within 7 days, no current fever or chills suggestive of acute symptomatic UTI, and bacterial colony count of $\geqslant 10^{4}$ colonies per milliliter based on urine cultures. ${ }^{5}$ There were no additional criteria in the study by Linsenmeyer et al. ${ }^{6}$ Four studies evaluated cranberry and prevention; ${ }^{6,11,18,19}$ one evaluated cranberry and treatment. ${ }^{5}$ A summary of the studies is provided in Tables 1 and 2.

\section{Cranberry for prevention}

A total of 388 participants were randomized to intervention or control for preventing UTIs. Participant characteristics of each study are in Table 3 . The methodological quality of the trials seemed rigorous. Studies by Lee et al., Hess et al., and Linsenmeyer et al. were randomized, double-blinded, and controlled trials; Hess et al. and Linsenmeyer et al. also contained crossover designs. ${ }^{6,11,19}$ The fourth trial, a pilot study conducted by Reid et al., contained an open crossover design. $^{18}$

Linsenmeyer et al. and Hess et al. included intervention and placebo groups, ${ }^{6,11}$ Linsenmeyer et al. also included a 1-week washout period in between. ${ }^{6}$ Reid et al. had participants add $3 \times 250 \mathrm{ml}$ water to their regular diet for 1 week followed by the intervention $(3 \times 250 \mathrm{ml}$ commercial cranberry juice, Ocean Spray Cranberries, Lakeville, MA, USA) for 1 week. ${ }^{18}$ Lastly, Lee et al. randomly assigned patients to one of the four groups using a factorial design, the groups being cranberry and Methenamine Hippurate (a urinary antiseptic, which suppresses or eliminates bacteriuria in the uroepithelial cells), cranberry and Methenamine Hippurate placebo, Methenamine Hippurate and cranberry 
Table 1 Cranberry to prevent urinary tract infections in the spinal cord injury population

\begin{tabular}{|c|c|c|c|c|c|}
\hline Author & Participants & Design & Intervention & Measurements & Results \\
\hline Hess et al. ${ }^{11}$ & $\begin{array}{l}47 \text { participants with } \\
\mathrm{SCl} \text { and neurogenic } \\
\text { bladder. }\end{array}$ & $\begin{array}{l}\text { Randomized, double- } \\
\text { blind, placebo- } \\
\text { controlled trial with a } \\
\text { crossover design. }\end{array}$ & $\begin{array}{l}500 \text { mg cranberry } \\
\text { extract tablet or } \\
\text { placebo for } 6 \text { months } \\
\text { followed by alternate } \\
\text { preparation for } \\
\text { additional } 6 \text { months. }\end{array}$ & $\begin{array}{l}\text { Primary outcome was } \\
\text { incidence of UTI. }\end{array}$ & $\begin{array}{l}\text { Reduction in the } \\
\text { likelihood of UTI and } \\
\text { symptom for any } \\
\text { month while receiving } \\
\text { cranberry tablet } \\
(P<0.05 \text { for all). }\end{array}$ \\
\hline Linsenmeyer et al. ${ }^{6}$ & $\begin{array}{l}21 \text { participants with } \\
\text { neurogenic bladder } \\
\text { secondary to } \mathrm{SCl} \text {. }\end{array}$ & $\begin{array}{l}\text { Prospective, } \\
\text { randomized, double- } \\
\text { blinded, placebo- } \\
\text { controlled crossover } \\
\text { study. }\end{array}$ & $\begin{array}{l}3 \times 400 \text { mg cranberry } \\
\text { tablets or placebo } \\
\text { for } 4 \text { weeks followed } \\
\text { by } 1 \text {-week washout } \\
\text { and } 4 \text { week crossover } \\
\text { to other group. }\end{array}$ & $\begin{array}{l}\text { Favorable or } \\
\text { unfavorable response } \\
\text { to cranberry } \\
\text { supplement vs placebo } \\
\text { on urinary bacterial } \\
\text { counts, WBC counts } \\
\text { and the combination } \\
\text { of bacterial and WBC } \\
\text { counts. }\end{array}$ & $\begin{array}{l}\text { No difference in urinary } \\
\mathrm{pH} \text { of cranberry } \\
\text { supplement }(\mathrm{pH}=5.9) \text { vs } \\
\text { placebo }(\mathrm{pH}=5.9) \text {. No } \\
\text { statistically significant } \\
\text { treatment effect for } \\
\text { cranberry tablets beyond } \\
\text { the placebo effect when } \\
\text { evaluating urinary } \\
\text { bacterial count } \\
(P=0.96) \text {, urinary WBC } \\
\text { count }(P=0.27) \text {, or } \\
\text { urinary bacterial and } \\
\text { WBC counts in } \\
\text { combination }(P=0.27) .\end{array}$ \\
\hline Reid et al. ${ }^{18}$ & $\begin{array}{l}15 \text { participants with } \\
\text { SCI and history of UTI. }\end{array}$ & $\begin{array}{l}\text { Pilot study with open } \\
\text { crossover design to } \\
\text { determine whether } \\
\text { alteration of fluid } \\
\text { intake and use of } \\
\text { cranberry juice affects } \\
\text { biofilm regeneration. }\end{array}$ & $\begin{array}{l}3 \times 250 \mathrm{ml} \text { water for } \\
7 \text { days followed by } \\
3 \times 250 \mathrm{ml} \text { per day } \\
\text { commercial cranberry } \\
\text { juice for } 7 \text { days. }\end{array}$ & $\begin{array}{l}\text { Urine samples were } \\
\text { used to harvest } \\
\text { uroepithelial cells to } \\
\text { look for biofilm coating } \\
\text { and to test for bacterial } \\
\text { adhesion. }\end{array}$ & $\begin{array}{l}\text { Cranberry juice intake } \\
\text { reduced biofilm load } \\
\text { compared with baseline } \\
(P=0.013) \text { and adhesion } \\
\text { of Gram-negative } \\
(P=0.054) \text { and Gram- } \\
\text { positive }(P=0.022) \\
\text { bacteria to cells. Water } \\
\text { intake had no effect on } \\
\text { bacterial adhesion or } \\
\text { biofilm presence. }\end{array}$ \\
\hline Lee et $a .^{19}$ & $\begin{array}{l}305 \text { participants with } \\
\text { SCI with neurogenic } \\
\text { bladder and stable } \\
\text { bladder management. }\end{array}$ & $\begin{array}{l}\text { Double-blind, } \\
\text { factorial-design } \\
\text { randomized- } \\
\text { controlled trial. }\end{array}$ & $\begin{array}{l}\text { Methenamine } \\
\text { Hippurate } 1 \mathrm{~g} \text { twice } \\
\text { daily and/or } 800 \mathrm{mg} \\
\text { cranberry twice daily } \\
\text { and/or placebo. End } \\
\text { point was occurrence } \\
\text { of symptomatic UTI. }\end{array}$ & $\begin{array}{l}\text { Time to occurrence } \\
\text { of symptomatic UTI. }\end{array}$ & $\begin{array}{l}\text { Both treatment groups } \\
\text { had no longer UTI-free } \\
\text { periods than placebo } \\
\text { groups ( } P=0.75 \text { for } \\
\text { Methenamine } \\
\text { Hippurate; } P=0.70 \text { for } \\
\text { cranberry). }\end{array}$ \\
\hline
\end{tabular}

Abbreviations: SCI, spinal cord injury; UTI, urinary tract infections.

Table 2 Cranberry to treat urinary tract infections in the spinal cord injury population

\begin{tabular}{|c|c|c|c|c|c|}
\hline Author & Participants & Design & Intervention & Measurements & Results \\
\hline Waites et al. ${ }^{5}$ & $\begin{array}{l}48 \text { individuals with } \\
\mathrm{SCl} \text { and neurogenic } \\
\text { bladder managed by } \\
\text { intermittent } \\
\text { catheterization or } \\
\text { external collection } \\
\text { device and a baseline } \\
\text { urine culture showing } \\
\text { at least } 10^{5} \text { colonies } \\
\text { per milliliter of bacteria. }\end{array}$ & $\begin{array}{l}\text { Randomized, } \\
\text { double-blinded, } \\
\text { placebo-controlled } \\
\text { study. }\end{array}$ & $\begin{array}{l}\text { Daily ingestion of } \\
\text { capsules with } 2 \mathrm{~g} \\
\text { of concentrated } \\
\text { cranberry juice or } \\
\text { placebo for } 6 \text { months. }\end{array}$ & $\begin{array}{l}\text { Baseline urinalysis } \\
\text { and cultures were } \\
\text { performed at the } \\
\text { time of the initial } \\
\text { clinic visit and monthly } \\
\text { for } 6 \text { months. }\end{array}$ & $\begin{array}{l}\text { No differences or trends } \\
\text { detected between } \\
\text { participants and controls } \\
\text { with respect to number } \\
\text { of urine specimens with } \\
\text { bacterial counts of at } \\
\text { least } 10^{4} \text { colonies per } \\
\text { milliliter, types and } \\
\text { numbers of different } \\
\text { bacterial species, } \\
\text { numbers of urinary } \\
\text { leukocytes, urinary } \\
\text { pH, or episodes of } \\
\text { symptomatic UTI. }\end{array}$ \\
\hline
\end{tabular}

Abbreviation: $\mathrm{SCl}$, spinal cord injury. 
Table 3 The characteristics of participants in each study

\begin{tabular}{|c|c|c|c|c|c|}
\hline & $\begin{array}{l}\text { Hess et al. } \\
(2008)^{11}\end{array}$ & $\begin{array}{l}\text { Linsenmeyer et al. } \\
(2004)^{6}\end{array}$ & $\begin{array}{l}\text { Reid et al. } \\
(2001)^{18}\end{array}$ & $\begin{array}{l}\text { Lee et al. } \\
(2007)^{19}\end{array}$ & $\begin{array}{l}\text { Waites et al. } \\
\qquad(2004)^{5}\end{array}$ \\
\hline \multirow[t]{2}{*}{$\mathrm{N}$} & 47 & 21 & 15 & 305 & 48 \\
\hline & $\begin{array}{c}\text { Median: } 52 \\
\text { (range: } 28-79 \text { ) }\end{array}$ & $N A$ & $\begin{array}{c}\text { Mean }=42.3 \pm 14.9 \\
\text { years }\end{array}$ & $\begin{array}{c}\text { Mean }=43.5 \pm 13.5 \\
\text { years }\end{array}$ & $\begin{array}{c}\text { Mean }=41 \\
\text { (range: } 20-73 \text { ) }\end{array}$ \\
\hline Age & $n(\%)$ & $n(\%)$ & $n(\%)$ & $n(\%)$ & $n(\%)$ \\
\hline \multicolumn{6}{|l|}{ Gender } \\
\hline Male & $47(100)$ & $16(76)$ & $10(67)$ & $252(83)$ & $42(88)$ \\
\hline Female & $0(0)$ & $5(24)$ & $4(27)$ & $53(17)$ & $6(18)$ \\
\hline \multicolumn{6}{|l|}{ Level of injury } \\
\hline Paraplegia & $24(51)$ & $13(62)$ & NA & $138(45)$ & $34(71)$ \\
\hline Tetraplegia & $23(49)$ & $8(38)$ & NA & $167(55)$ & $14(29)$ \\
\hline \multicolumn{6}{|l|}{ Completeness of injury } \\
\hline Complete & $27(57)$ & NA & NA & $148(49)$ & $40(83)$ \\
\hline Incomplete & $20(43)$ & NA & NA & $157(51)$ & $8(17)$ \\
\hline \multicolumn{6}{|l|}{ Bladder management } \\
\hline Reflex voiding/condom catheter & $35(74)$ & $4(19)$ & NA & 59 (19) & $0(0)$ \\
\hline Intermittent catheterization & $8(17)$ & $12(57)$ & NA & $90(30)$ & $25(52)$ \\
\hline Indwelling catheter & $4(9)$ & $0(0)$ & NA & $156(51)$ & $0(0)$ \\
\hline Foley catheter & $0(0)$ & $4(19)$ & NA & $0(0)$ & $0(0)$ \\
\hline External collection & $0(0)$ & $0(0)$ & NA & $0(0)$ & $23(48)$ \\
\hline Not stated & $0(0)$ & $1(5)$ & NA & $0(0)$ & $0(0)$ \\
\hline
\end{tabular}

placebo, or cranberry placebo and Methenamine Hippurate placebo. ${ }^{19}$ The rationale for the type or dosage of cranberry given to participants was not mentioned in any of the trials. Of the three studies using cranberry extract tablets, Hess et al. had participants consume $500 \mathrm{mg}$ each day (CranMax, Swiss Herbal, Canada), ${ }^{11}$ whereas Linsenmeyer et al. had participants consume $3 \times 400 \mathrm{mg}$ each day (Nature's Way, Springville, Utah), ${ }^{6}$ and Lee et al. used $2 \times 800 \mathrm{mg}^{19}$

The attrition rate of the four trials varied considerably. Reid et al. reported no dropouts, all 15 participants completed the study. ${ }^{18}$ Hess et al. had 10 dropouts; however, the 47 participants who completed the study were all reportedly compliant. ${ }^{11}$ Lee et al. included all 305 participants in the analysis despite 55 dropouts; this attrition rate seems high, but sufficient participants were recruited to allow for a $20 \%$ dropout rate. ${ }^{19}$ Lastly, there were 16 dropouts reported in the study by Linsenmeyer et al.; any differences between the dropouts and the 21 participants who completed the study were not mentioned. ${ }^{6}$

The four studies conducted measurements relating to the prevention of UTIs; intervention/placebo was given to those without a symptomatic UTI, if an infection occurred at any point during the study participants stopped the intervention/placebo and were treated before continuing participation. Hess et al.'s ${ }^{11}$ primary outcome was the incidence of symptomatic UTI, defined as: (1) the presence of $>10^{4}$ organisms per milliliter of urine, (2) the presence of one or more new symptoms, and (3) evidence of tissue invasion such as hematuria ( $\geqslant 4 \mathrm{RBC} / \mathrm{HPF}$ ) or pyuria ( $\geqslant 10$ white blood cell, WBC/HPF). ${ }^{11}$ Lee et al.'s primary outcome was the time to occurrence of a symptomatic UTI, as this is the current criterion for treating patients with SCI. ${ }^{19}$ In this study, UTI was defined according to the 1992 National Institute on Disability and Rehabilitation Research Statement on symptomatic UTIs in the spinal cord injured. ${ }^{10}$ Linsenmeyer et al. determined a response to cranberry vs placebo on the basis of urinary bacterial counts, WBC counts, and the combination of bacterial and WBC counts. ${ }^{6}$ Bacteriuria was considered significant with $\geqslant 10^{4}$ colonies per milliliter for a clean voided specimen and $\geqslant 10^{2}$ colonies per milliliter for a specimen obtained by intermittent catheterization and pyuria was defined as WBC count $\geqslant 10$ per high power field in centrifuged urine. ${ }^{6}$ Finally, Reid et al . determined biofilm load (aggregate of microbes) compared with baseline and tested for bacterial adhesion. ${ }^{18}$

Predictably, the results of the four studies are conflicting. Two studies showed no evidence of preventative effect when using cranberry. ${ }^{6,19}$ Lee et al. reported no statistically significant effect of cranberry tablets compared with placebo $(P=0.70) .{ }^{19}$ Linsenmeyer reported no difference in overall 4-week urinary $\mathrm{pH}$ in individuals on cranberry supplement vs placebo $(\mathrm{pH}=5.9$ for both) and no statistically significant effect for cranberry tablets vs placebo for evaluating urinary bacterial count $(P=0.96)$, urinary WBC count $(P=0.27)$, or urinary bacterial and WBC counts in combination $(P=0.27) .{ }^{6}$ Conversely, two studies showed evidence of a preventative effect of cranberry. The results of the study conducted by Reid et al. showed that cranberry juice intake significantly reduced biofilm load compared with baseline $(P=0.013)$ because of a reduction in adhesion of Gramnegative $(P=0.054)$ and Gram-positive $(P=0.022)$ bacteria to cells. ${ }^{18}$ Hess et al. found no difference in the incidence of significant bacteriuria between cranberry and placebo groups $(P=0.52)$; however, they found fewer UTIs during the cranberry period $(P=0.01){ }^{11}$ 
Adverse reactions experienced by participants were mild in nature and occurred in 15 participants in two studies. ${ }^{6,19}$ The reported adverse reactions were diarrhea, constipation, nausea, rash, and abdominal discomfort. ${ }^{6,19}$ Reid et al. and Hess et al. did not mention any adverse reactions. ${ }^{11,18}$

\section{Cranberry for treatment}

One randomized, double-blind, placebo-controlled study conducted by Waites et al. ${ }^{5}$ was included, which investigated whether cranberry extract would reduce or eliminate bacteriuria and pyuria in individuals with SCI. Participants with SCI and neurogenic bladder managed by intermittent catheterization or external collection device and asymptomatic bacteriuria (a baseline urine culture showing at least $10^{5}$ colonies per milliliter of bacteria) were randomized to intervention or control. ${ }^{5}$ Participant characteristics are in Table 3 . Each participant ingested $2 \times 1 \mathrm{~g}$ of concentrated cranberry juice in capsule form (CranVerry, Aim This Way, Cambridge, Mass) or placebo in capsule form daily for 6 months. ${ }^{5}$ The rationale for the type or dosage of cranberry given to participants was not mentioned.

The methodological design of this study was rigorous, although 26 of 74 participants withdrew after beginning the study, for various reasons. ${ }^{5}$ An unspecified number of participants withdrew from the study with the perception that the cranberry supplement caused adverse effects. ${ }^{5}$ Specific adverse reactions were not mentioned. ${ }^{5}$ The 48 who completed the study were all reportedly compliant. ${ }^{5}$

Baseline urinalysis and cultures were performed at the time of the initial clinic visit and monthly for 6 months. ${ }^{5}$ The results showed no evidence of treatment effect of cranberry extract to reduce bacteriuria or pyuria. ${ }^{5}$ There were no differences or trends detected between participants and controls with respect to number of urine specimens with bacterial counts of at least $10^{4}$ colonies per milliliter $(P=0.758)$, types and numbers of different bacterial species, numbers of urinary leukocytes $(P=0.929)$, urinary $\mathrm{pH}$ $(P=0.659)$, or episodes of symptomatic UTI $(38.5 \%$ intervention vs $36.4 \%$ controls). ${ }^{5}$

\section{Conclusion}

It is important that conclusions be drawn about the use of cranberry to prevent or treat UTIs in this population given that UTIs are the most common secondary medical complication reported..$^{5-10}$

In the SCI population, the use of cranberry to prevent or treat UTI does not offer encouraging results. Two clinical studies (Table 1) suggest a possible clinical benefit of cranberry extract tablets and commercial cranberry juice in preventing UTIs in the SCI population; two do not. These latter two studies, which report no benefit in cranberry consumption, provide an adequate sample size, rigorous methodology, and investigated numerous measurements to suggest not recommending cranberry to prevent UTIs in the SCI population. The one clinical study noted no difference in treatment of UTIs in the cranberry group vs the placebo group (Table 2). However, there was only one study carried out in this area. Although there is generally negative evidence presented in regards to cranberry's effectiveness in the prevention or treatment of UTIs, further clinical research must be carried out to reach a conclusion. Future studies must take into account the positive effect of cranberries on bacteriuria with pyuria can take up to 1 month to manifest, and may need an additional 4 weeks before any benefit is seen. ${ }^{33}$

Conducting research in the SCI population is challenging, as it is smaller than the able-bodied population and very diverse in terms of demographics, level of injury, chronic disease, secondary impairment experiences, and various types of bladder management. This provides difficulty in having truly balanced study groups, particularly in small studies. Current research is inconclusive and has many limitations including failure to balance adequately for bladder management type, failure to recruit target number of participants, short study duration, high dropout rate, lack of information on the difference between participants who completed the study and those who did not, lack of washout period, and different definitions of symptomatic UTI. A strength of current research is the randomized, doubleblinded, placebo-controlled study designs.

For future research to be generalizable to the adult SCI population, participants need to better represent the population (that is demographics, level of injury, traumatic vs nontraumatic injury, and various types of bladder management). Studies need to be larger, longer in duration, investigate various doses of cranberry, and use various methods to observe whether cranberry is effective in preventing UTIs (that is urine cultures, bacterial counts, WBC counts). Future research should justify various types and dosage of cranberry and how dropouts may differ from participants who complete the study. Adverse effects also need to be investigated and reported. Lastly, research needs to use a standardized definition of UTI on which they can base conclusions about cranberry and its effectiveness.

\section{Conflict of interest}

The author declares no conflict of interest.

\section{Acknowledgements}

Many thanks to Dr Andrea C Buchholz for her guidance and work in editing the early drafts of this review.

\section{References}

1 Salomon J, Denys P, Merle C, Chartier-Kastler E, Perronne C, Gaillard JL et al. Prevention of urinary tract infection in spinal cord-injured patients: safety and efficacy of a weekly oral cyclic antibiotic (WOCA) programme with a 2 year follow-up-an observational prospective study. J Antimicrob Chemother 2006; 57: 784-788.

2 Spinal Cord Injury Solutions Network. Spinal cord injury solutions network. 2008; Available at: http://www.scisolutions network.ca/ Accessed February 2009.

3 Cardenas DD, Hooton TM. Urinary tract infection in persons with spinal cord injury. Arch Phys Med Rehabil 1995; 76: 272-279. 
4 Dorsett P, Geraghty T. Health-related outcomes of people with spinal cord injury-a 10 year longitudinal study. Spinal Cord 2008; 46: 386-391.

5 Waites KB, Canupp KC, Armstrong S, De Vivo MJ. Effect of cranberry extract on bacteriuria and pyuria in persons with neurogenic bladder secondary to spinal cord injury. I Spinal Cord Med 2004; 27: 35-40.

6 Linsenmeyer TA, Harrison B, Oakley A, Kirshblum S, Stock JA, Mills SR. Evaluation of cranberry supplement for reduction of urinary tract infections in individuals with neurogenic bladders secondary to spinal cord injury. A prospective double-blinded, placebo-controlled, crossover study. J Spinal Cord Med 2004; 27: 29-34.

7 Gupta A, Taly AB, Srivastava A, Murali T. Non-traumatic spinal cord lesions: epidemiology, complications, neurological and functional outcome of rehabilitation. Spinal Cord 2009; 47: 307-311.

8 Biering-Sørensen F. Urinary tract infection in individuals with spinal cord lesion. Curr Opin Urol 2002; 12: 45-49.

9 Shekelle PG, Morton SC, Clark KA, Pathak M, Vickrey BG. Systematic review of risk factors for urinary tract infection in adults with spinal cord dysfunction. J Spinal Cord Med 1999; 22: 258-272.

10 National Institute on Disability and Rehabilitation Research Statement. The prevention and management of urinary tract infections amongst people with spinal cord injuries. I Am Paraplegia Soc 1992; 15: 194-204.

11 Hess MJ, Hess PE, Sullivan MR, Nee M, Yalla SV. Evaluation of cranberry tablets for the prevention of urinary tract infections in spinal cord injured patients with neurogenic bladder. Spinal Cord 2008; 46: 622-626.

12 Jaglal SB, Munce SEP, Guilcher SJ, Couris CM, Fung K, Craven BC et al. Health system factors associated with rehospitalizations after traumatic spinal cord injury: a population-based study. Spinal Cord 2009; 47: 604-609.

13 Reid G, Nicolle L. Asymptomatic bacteriuria in spinal cord injured patients and elderly. Urol Clin $N$ Am 1999; 26: 789-795.

14 Waites KB, Canupp KC, Devivo MJ. Epidemiology and risk factors for urinary tract infection following spinal cord injury. Arch Phys Med Rehabil 1993; 74: 691-695.

15 Ruz AED, Leoni EG, Cabrera RH. Epidemiology and risk factors for urinary tract infection in patients with spinal cord injury. J Urol 2000; 164: 1285-1289.

16 Woodbury MG, Hayes KC, Askes HK. Intermittent catheterization practices following spinal cord injury: a national survey. Can J Urol 2008; 15: 4065-4071.

17 García Leoni ME, Esclarín De Ruz A. Management of urinary tract infection in patients with spinal cord injuries. Clin Microbiol Infect 2003; 9: 780-785.
18 Reid G, Hsiehl J, Potter P, Mighton J, Lam D, Warren D et al. Cranberry juice consumption may reduce biofilms on uroepithelial cells: pilot study in spinal cord injured patients. Spinal Cord 2001; 39: 26-30.

19 Lee BB, Haran MJ, Hunt LM, Simpson JM, Marial O, Rutkowski SB et al. Spinal-injured neuropathic bladder antisepsis (SINBA) trial. Spinal Cord 2007; 45: 542-550.

20 Kuhlemeir KV, Stover SL, Lloyd LK. Prophylactic antibacterial therapy for preventing urinary tract infection in spinal cord injury patients. J Urol 1985; 143: 514-517.

21 Opperman EA, Buchholz AC, Darlington GA, Martin Ginis KA, The SHAPE-SCI research group. Dietary supplement use in the spinal cord injury population. Spinal Cord (e-pub ahead of print 7 July 2009).

22 Sobota AE. Inhibition of bacterial adherence by cranberry juice: potential use for the treatment of urinary tract infections. J Urol 1984; 131: 1013-1016.

23 Henig YS, Leahy MM. Cranberry juice and urinary-tract health: science supports folklore. Nutrition 2000; 16: 684-687.

24 Schmidt DR, Sobota AE. An examination of the anti-adherence activity of cranberry juice on urinary and nonurinary bacterial isolates. Microbios 1988; 55: 173-181.

25 Habash MB, Van der Mei HC, Busscher HJ, Reid G. The effect of water, ascorbic acid, and cranberry derived supplementation on human urine and uropathogen adhesion to silicone rubber. Can J Microbiol 1999; 45: 691-694.

26 Lynch DM. Cranberry for prevention of urinary tract infections. Am Fam Physician 2004; 70: 2175-2177.

27 Ofek I, Goldhar J, Sharon N. Anti-Escherichia coli adhesion activity of cranberry and blueberry juices. Adv Exp Med Biol 1996; 408: 179-183.

28 Zafriri D, Ofek I, Adar R, Pocino M, Sharon N. Inhibitory activity of cranberry juice on adherence of type 1 and type $P$ fimbriated Escherichia coli to eucaryotic cells. Antimicrob Agents Chemother 1989; 33: 92-98.

29 Ofek I, Goldhar J, Zafriri D, Lis H, Adar R, Sharon N. AntiEscherichia coli adhesin activity of cranberry and blueberry juices. N Engl J Med 1991; 324: 1599.

30 Howell AB, Vorsa N, Der Marderosian A, Foo LY. Inhibition of the adherence of P-fimbriated Escherichia coli to uroepithelial-cell surfaces by proanthocyanidin extracts from cranberries. $\mathrm{N} \mathrm{Engl} \mathrm{J}$ Med 1998; 339: 1085-1086.

31 Harkins KJ. What's the use of cranberry juice? Age Ageing 2000; 29: 9-12.

32 Jepson RG, Craig JC. Cranberries for preventing urinary tract infections. Cochrane Database of Systematic Reviews 2008, Issue 1. Art. No.: CD001321; doi:10.1002/14651858.CD001321.pub4 (http://www.cochrane.org/reviews/en/ab001321.html).

33 Avorn J, monane M, Gurwitz JH, Glynn RJ, Choodnovskiy I, Lipstiz LA. Reduction of bacteriuria and pyuria after ingestion of cranberry juice. J Am Med Assoc 1994; 271: 751-754. 